\title{
The World Journal of Surgery Welcomes Dr. Julie Miller to the Editorial Board
}

\author{
Julie Ann Sosa ${ }^{1}$
}

Accepted: 7 April 2021/Published online: 20 April 2021

(C) Société Internationale de Chirurgie 2021

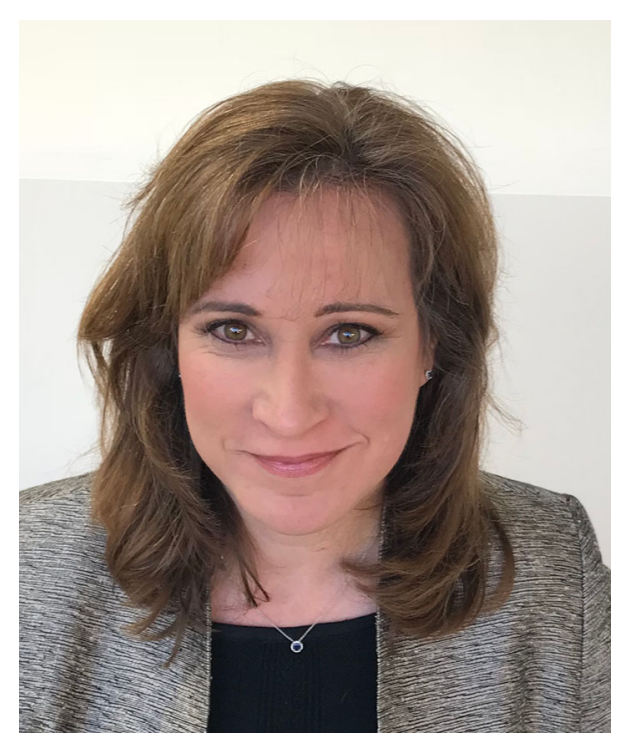

Dr. Julie Miller is a native Texan who studied medicine at Washington University in St Louis and then completed her surgical training at The New York Hospital and Memorial Sloan Kettering Cancer Center. She then moved to Australia and commenced practice in general and endocrine surgery at The Royal Melbourne Hospital.

She is currently serving as Head of Endocrine Surgery at The Royal Melbourne Hospital and Associate Professor of Surgery at The University of Melbourne, as well as President of Australian/New Zealand Endocrine Surgeons. Her clinical research interests include management of adrenal tumours, particularly pheochromocytomas, thyroid cancer management and quality of life, and regional variations in practice.

She spends her non-work time raising her three children, loves travel, and is an enthusiastic women's cricketer, playing as a batting all-rounder. In fact, she may be the world's only endocrine surgeon Texan women's cricket captain. Twitter: @DrJulieAMiller.

Publisher's Note Springer Nature remains neutral with regard to jurisdictional claims in published maps and institutional affiliations.
Julie Ann Sosa, MD, MA, FACS—Editor in Chief, World Journal of Surgery.

Julie Ann Sosa

julie.sosa@ucsf.edu

1 University of California at San Francisco-UCSF, San Francisco, USA 